\title{
The ACRL Annual Report, 1953-54
}

\section{Introduction}

7 HE PRINCIPAL BUSINESS of the association is published as the "Brief of Minutes" of directors' meetings in the April and October issues of C\&RL. The Newsletters of several of the sections give further data. The Summary Reports of the Midwinter and Annual Conferences record programs and business handled by sections and by committees. Vital statistics of the division, names of all officers and committee members and other information are given in the organization issue (December) of the ALA Bulletin. Reference is also made to "Notes from the ACRL Office" which I write for most issues of the official journal.

Much of this report was, of course, prepared by section and committee chairmen, whose initials are used to indicate their authorship.

The year under review seems, in retrospect, to have been largely a year of normal and satisfactory routine operation and consolidation of previous commitments. There were no great new ventures or spectacular accomplishments.

\section{Membership and Finances}

During the fiscal year, 5128 members joined ACRL. This is 349 more than any previous year. This increase of $7 \%$ indicates a healthy interest in this division. It is no more than a healthy growth, and is not cause for self-complacency.

As noted on the accompanying treasurer's report, ACRL ended the year's work with a deficit of $\$ 3,451.55$. This is the first real deficit in a good many years and does not reflect an unhealthy condition. ACRL is not operated for profit and its reserve fund has been greater than required by prudence or planned future program. Salaries of the two new positions at headquarters are, of course, the principal cause of the deficit.

\section{Publications}

COLLEGE AND RESEARCH LIBRARIES continues its useful service under the editorship of Maurice F. Tauber. It has grown in size to the point where nearly every issue is $128 \mathrm{pp}$. Approximately 5000 members of ACRL receive copies as well as 700 non-member subscribers. Sales of single copies bring in a small revenue.

For some years the $A L A$ Bulletin, for a fee, handled the production of COLLEGE AND
RESEARCH LIBRARIES (production includes styling the manuscript, seeing it through the press, placing the ads, etc.). By friendly agreement, this arrangement was terminated last year. The October issue was brought out by Miss Sabusawa of the $A L A$ Bulletin staff and the January issue by Mr. Hamlin. Production is now handled by the new publications officer, Mrs. Cynthia Spigelman.

Income from COLLEGE AND RESEARCH LIBRARIES subscriptions, advertising, and back copy sales totalled $\$ 8,815.37$ and all expenses came to $\$ 12,275.05$. Cost for the year's operation was, therefore, approximately $\$ 3,460.00$.

The new position of ACRL publications officer means, among other things, that more time can be devoted to solicitation of advertisements and assistance to the editor. This help frees the executive secretary from many duties connected with the distribution of COLLEGE AND RESEARCH LIBRARIES and maintenance of membership records, as well as the advertising work and other COLLEGE AND RESEARCH LIBRARIES responsibilities.

The year's progress with the ACRL MONOGRAPHS is reported by the Publications Committee chairman (below). The MONOGRAPHS continue to pay their way in satisfactory fashion. The publications officer devoted considerable attention to the promotion of the 
MONOGRAPHS. Review copies of the two new numbers were distributed widely and received much favorable notice. More than 5000 copies of a circular describing the ACRL MONOGRAPHS were sent out by mail.

\section{Travel}

A good deal of an executive secretary's time must go to travel and public speaking. I spoke at meetings of librarians (usually the state association) in Florida, Missouri, Kentucky, West Virginia, Michigan and New York. Other meetings and association business took me to libraries in eighteen states. Less time was spent in travel during the first part of the year because responsibility for the production of COLLEGE AND RESEARCH LIBRARIES took a great deal of time. I was particularly glad to be able to attend three ACRL chapter meetings. Such invitations have priority.

\section{Student Reading Habits}

ACRL can perform a great service to education by making contributions to raise the college student's level of reading. One of the most serious defects of higher education today is its frequent failure to create in students the desire to know, the habit of personal investigation, and a real familiarity with books and enjoyment of them. We are approaching a long period of rapidly spiralling enrollments in our colleges. Instruction today is all too impersonal and will undoubtedly become more and more so. The personal influence of teacher on student will progressively diminish. In this situation the library must take increasing responsibility for the development of habits of good reading. ACRL can and should call attention to the importance of the need, foster discussion, and seek such solutions as it can through its own committees and sections and in cooperation with publishing and other education associations.

A good deal of personal attention was devoted to this problem, which was discussed at length in the July, 1954, issue of COLLEGE AND RESEARCH LIBRARIES.

As your secretary, I called a small, informal conference of librarians and publishers at the Midwinter meeting. This group examined the use of inexpensive books on college campuses.
In the spring, a group of librarians prepared working papers on aspects of this subject and an all-day conference was held in New York City. Arrangements for the meeting were made by the Committee on Reading Development of the American Book Publishers Council. More than a score of librarians from that area were invited and attended, as well as a similar number of publishers operating in the low-price field. From this discussion came agreement on a number of steps to be taken by publishers and librarians to make these books more useful and, we hope, to build better habits of book use.

Furthermore, ACRL should give more attention to the responsibility of the college library to the reading community beyond the campus gates. Just prior to writing this report, I attended the meeting of the Pacific Northwest Library Association in Tacoma and heard five librarians report on general library developments in their respective states and provinces. Each of these reports stressed the over-all development of library service (by all types of libraries) to the citizens, and three of these reports were given by state library leaders who headed college libraries. Only a few years before, I had visited the librarian of a city library in the Pacific Northwest and had been told, in a friendly way, that college libra rians too often consider themselves a cut above other librarians, that it was time they joined cause with their colleagues and worked for the advancement of libraries in general. There at Tacoma was the answer.

Those who attended the ACRL meetings at Minneapolis are aware of the important pioneering work in adult education being done by the University of Utah Library. Another example is Oklahoma $A \& M$; a third is Texas Technological College in Lubbock. I do not know the proper sphere for ACRL action in this area, but believe the trend is healthy and that the Association should watch developments by college libraries in the adult education field and be ready to assist with cooperative action whenever practicable.

Too frequently in the past our college librarians have not taken part in movements to extend or improve public library services or to promote federal legislation which will ease the labors of other librarians. We all have responsibilities to speak out on policies which concern any type of library, and especially in 
regard to any library legislation, whether urban, state or national. We will all be touched by the success or failure of school libraries, of bookmobile service and service to children. Our students are only a few months and a few miles removed from the school library and the home town librarian. Their use of books and libraries in college (or lack of it) depends to a considerable extent on their use of books and libraries (or lack of it) a few months before and a few miles away.

\section{Staff}

For four years two people made up the staff at ACRL headquarters. Part-time help was later added to help get out COLLEGE AND RESEARCH LIBRARIES and the ACRL MONOGRAPHS. As the publications program grew so did the need for more staff.

In January, 1954, Mrs. Cynthia Spigelman took over the new post of publications officer and Miss Janice Levenfeld joined us as clerk- typist. Miss Elaine Mitchell continues as the efficient secretary.

Mrs. Spigelman came to ACRL from the McGraw-Hill Publishing Company. She is a graduate of Columbia Library School and was previously on the staff of the Library of Congress.

I am indebted to the ALA staff for warmhearted cooperation at every turn during the past year at headquarters. The ACRL program has had considerable contact with the ALA Office of Adult Education and Mrs. Stevenson has made material contributions at various points. The divisional secretaries have informal weekly meetings over lunch with Mr. Clift and Mrs. Stevenson, and share news, gossip and problems as a matter of course. So far as ACRL is concerned, the working relationships at headquarters have been excellent this past year, and much credit for this should go to Mrs. Stevenson and Mr. Clift.

\section{Committees and Sections}

\section{Buildings Committee}

\section{(Charles M. Adams, Chairman)}

Activity among those planning new library buildings or making additions continues. Many letters concerning building problems were answered directly; other inquiries were referred to ALA Headquarters or to consultants in the field. A successful conference on new library building plans and building problems was held in the new library at the University of Wisconsin preceding Midwinter. The proceedings were published as ACRL MONOGRAPH No. II. Included in this monograph was a supplement to Edna Hanley Byers' bibliography on college and university library buildings for the periods I939-1945 and for 1953-1954 not covered in the ACRL MONOGRAPH No. IO.

The ACRL Buildings Committee cooperated with the ALA Buildings Committee in an ALA pre-conference institute at St. Paul in June. This institute was an example of successful cooperation which can result from the close integration of ACRL's committee work with that of the other divisions and with ALA as a whole. The continued cooperation of architects in presenting new building plans and papers at our meetings is to be com- mended. There is every indication that interest in building problems will be lively for a number of years and that the Buildings Committee has contributions to make for its members and for the profession.

(CMA)

\section{Committee on Committees}

\section{(Andrew J. Eaton, Chairman)}

At the 1954 Midwinter meeting the Board of Directors voted that the name of the Committee on Committee Appointments be changed to Committee on Committees with the following statement of purpose: "To study ACRL committees and to recommend the establishment or discontinuance of committees as the needs of the association require; to define the duties of committees subject to approval of the Board of Directors; to solicit recommendations for appointments to committees, and to transmit these recommendations with its own advice to the president and the presidentelect."

By the end of April the committee had agreed on a list of I I members for next year's committees, and had submitted the list to the president-elect. In preparing the list the committee attempted to give representation 
to the various types of libraries in the association, and to provide for as much rotation of assignment as possible without sacrifice of continuity. Advice was solicited and received from members of the Board of Directors, committee and section chairmen, state representatives, the president, the executive secretary, and selected individuals in various parts of the country. In addition, the new chairmen were invited to suggest changes or additions in the membership of their committees. The committee is grateful to all those who responded to its request for suggestions.

The committee studied proposals for the creation of several new committees, and presented its recommendations to the Board of Directors at the June meeting. At the same time it recommended the discontinuance of two committees for which there appeared to be no further need.

At the request of the Board of Directors the committee studied the statements of purpose of all ACRL committees, and recommended their tentative approval with the understanding that the incoming chairmen be encouraged to review the purposes of their committees and to suggest further changes during the coming year if they see fit. (AJE)

\section{Committee on Conference Programs}

\section{(Ralph H. Hopp, Chairman)}

The work of this committee is, for the most part, of a liaison nature. The activities for the past year consisted primarily of making local arrangements for ACRL meetings at the Minneapolis Conference. For this purpose the committee consisted of Roy Watkins, Hubert Sauter and Joseph Richardson, in addition to the chairman. William Budington assisted with the arrangements for the ACRL booth at the Conference.

( $\mathrm{RHH})$

\section{Duplicates Exchange Union}

\section{(Mrs. Dorsey L. MacDonald)}

The committee prepared a revised set of rules of procedure for the Duplicates Exchange Union. Revisions were based on criticisms and suggestions made by members in response to a questionnaire sent out in 1952 (see Mr. George F. Jones' report in Serial Slants, January, 1953, pp. 21-27). The suggested revisions were submitted to all members for voting. The new rules, incorporating changes approved by the majority of the members of the Union, were mailed to members in January, 1954 .

Printed leaflets describing the activities of the United States Book Exchange were mailed to all members.

A brief report on the committee's work was published in Serial Slants, January, 1954. The Union had 112 members at the end of the year.

(DLM)

\section{Publications Committee}

\section{(Lawrence S. Thompson, Chairman)}

During the year the ACRL MONOGRAPHS continued to grow in numbers of issues and in subscribers. Two new titles were published, representing the Proceedings of the 1953 and the 1954 Library Building Plans Institute. Standing orders for the ACRL MONOGRAPHS totaled 515 at the end of the year. This is an increase of some 60 standing orders over the previous year. Included among these are 44 foreign subscribers. Orders are received daily, as well, for single copies of back numbers. Largely due to the energy and wholehearted interest of David K. Maxfield, managing editor, the series has attracted manuscripts of broad interest to the entire college and reference library field, and there has been much favorable comment in the library press both in the United States and abroad.

The ACRL MICROCARD SERIES has now reached over thirty numbers, and there are over fifty standing orders for it. Abstracts are published regularly in COLLEGE AND RESEARCH LIBRARIES as well as in other leading periodicals devoted to librarianship and to subject fields as well.

(LST)

\section{Committee on Standards \\ (William H. Jesse, Chairman)}

At the 1954 Midwinter meeting, the ACRL Committee on Standards, then designated as the Committee on Administrative Procedures, redefined its function as being responsible for (I) the maintenance of library standards and support, (2) direction of development of standards for college libraries, and (3) work with accrediting associations on their instructions for the examination of libraries. Board approval for this description of purpose and for the change of name was secured.

The committee decided to direct its im- 
mediate efforts toward college rather than research libraries, since college libraries stand in greatest need of assistance in maintaining standards and in developing further standards. Although there was no meeting of the committee at Minneapolis, work has proceeded along the lines suggested by the chairman and the members. A very helpful annotated list of the literature on standards for college libraries was compiled by David Weber of Harvard. The chairman expects, through his chairmanship of the Committee on the Library of the Southern Association of Colleges and Secondary Schools, to establish some degree of communication with that association, and through it, possibly, with others.

(WHJ)

\section{ACRL State Representatives}

\section{(Archie L. McNeal, Chairman)}

Primary emphasis of the state representatives has continued to be placed on membership. Modest funds were provided for state representatives to make visits in their states for ACRL. Many state representatives responded to the invitation to submit the names of local people for committee assignments and nomination for elective office. A few representatives have been furnishing professional news to COLLEGE AND RESEARCH LIBRARIES.

The chairman kept in touch with representatives through a series of mimeographed newsletters. Meetings were held at Midwinter and the Annual Conference.

\section{(ALMcN and ATH)}

\section{Committee on Statistics}

\section{(G. Flint Purdy, Chairman)}

As usual the January, I955 issue of CoLLEGE AND RESEARCH LIBRARIES contains tangible evidence of the work of the Statistics Committee during the last year.

The committee met both at Midwinter and Annual Conference to discuss policies and procedures. It distributed a questionnaire to the mailing list regarding the reporting form to be used. On the basis of the returns, the form was revised and procedures altered. (See Dale Bentz' article, "An Evaluation of the ACRL Statistics Report" in this issue.)

The inclusion of statistics for junior college libraries was discussed. It is hoped that these can be included with other library statistics in the future.

(GFP)

\section{College Libraries Section}

\section{(Helmer L. Webb, Chairman)}

The principal activity of the section was in connection with the Midwinter and Annual Conference programs. No committees were active or projects undertaken. In a desire to get more general participation of the membership into the program, the Minneapolis Conference program consisted of five discussion groups. The section also had an informal luncheon on the University of Minnesota campus.

(ATH)

\section{Junior College Libraries Section}

\section{(Lottie M. Skidmore, Chairman)}

The program for the year was concentrated on statistics and standards for junior college libraries. Committees were established to carry on the work in each field. Under the chairmanship of Mrs. Thelma Vogt Taylor, extensive statistical data were collected for the first time on the operation of junior college libraries during 1952-53 and published in the Newsletter. Fifty institutions were covered. Plans were made to continue this work and publish the figures in COLLEGE AND RESEARCH LIBRARIES to reach a wider public.

Considerable progress was made in the difficult field of standards for junior college libraries. After intensive work, a "Tentative List of National Standards" was prepared under the chairmanship of Ruth Bradley. This was discussed at the Minneapolis Conference. After further study and revision, it will be issued in final form.

The Midwinter program subject was the use and selection of periodicals for junior college libraries; lists of periodical ratings prepared for this program were widely sought and all available mimeographed copies had been requested only a few weeks after the meeting. The topic for the annual conference was the junior college student.

Three Newsletters were issued to carry out the business of the section and to report to the members the proceedings of the section.

(LMS)

\section{Pure and Applied Science Section}

(Donald E. Thompson, Chairman)

During 1952-1953, A Recommended List of Basic Periodicals in Engineering Sciences was 
completed. This was published in July, I953, as ACRL MONOGRAPH No. 9.

At the Midwinter meeting in Chicago in February, I954, a group of projects was discussed. The one which evoked the most interest was a basic list of periodicals in agriculture and the agricultural sciences. Mrs. Margaret Bryant of the USDA Library was asked to prepare a proposed project to be presented at the Minneapolis meeting. The proposal was approved on June 22, 1954 by the membership present at the Minneapolis meeting. The new chairman will appoint a committee to begin work on the project.

At the Midwinter meeting, Mr. James G. Hodgson of Colorado A\&M College presented a proposal to microfilm the catalog cards of certain portions of the card catalog at the U. S. Waterways Experiment Station Library in Vicksburg, Mississippi. The chairman requested $M r$. Hodgson to investigate further and make a report at a later PASS meeting.

A dinner meeting was held in Chicago on February 4, 1954 with approximately 70 people present. The program consisted mostly of business and projects. William Hyde and Carson Bennett discussed the engineering periodicals list. Lawrence Thompson gave a short talk on foreign exchanges.

The meeting in Minneapolis was held at the University of Minnesota on June 22, 1954 with approximately 100 people attending. The program was based on the natural resources of the Minnesota area. Dr. George A. Thiel spoke on mineral industries, Dr. Frank H. Kaufert spoke on the forest industry, and Mr. Gordon Michaelson spoke on the oil industry.

(DET)

\section{Libraries of Teacher Training Institutions Section}

\section{(James E. Green, Chairman)}

A very considerable part of the section's energies during the past year were concentrated on working toward the revision of Standard VII (The Library) of the American Association of Colleges for Teacher Education visitation program. Under the chairmanship of Donald Woods, the committee working on this project sent out a questionnaire to several hundred teachers' college librarians to get their reactions to the visita- tion program as it affected their library. It was felt generally that the standard marks a very substantial advance in evaluative criteria for college libraries and was very much worth additional work.

The section chairman, Mr. Woods, and Mr. Hamlin met with the AACTE Standards Committee to discuss further revision in the standard and a full report was made to the section at the Midwinter meeting in Chicago.

(JEG)

\section{Reference Librarians Section}

\section{(Everett T. Moore, Chairman)}

A meeting of the section was held on February 3 in the Morrison Hotel during the ALA Midwinter Conference. Miss Florence Gifford presided. Mr. N. Owin Rush addressed the group on "A Fulbright Family in England, with References to Research in English Libraries."

During a discussion of the idea of a reference librarians division in ALA, a motion was made and passed that the section chairman appoint a committee of members of the section to study the question and to make a report with recommendations at the Minneapolis meeting. It was suggested there might be a need for meetings of reference librarians of the large university and research libraries to discuss problems peculiar to that group.

For some years members of our section have given considerable thought to the question of whether the present organization of reference librarians within the ACRL provides the best possible structure for a grouping of members along functional lines. The chairman appointed a committee to study the question of establishing a reference division in the ALA. The chairman was Miss Winifred Ver Nooy, University of Chicago, and her committee members were Miss Mary $\mathrm{N}$. Barton, Enoch Pratt Free Library, and Mr. Milton C. Russell, Virginia State Library.

The committee reported in June that there appeared to be considerable divergence of opinion as to the best form of organization of the reference librarians of the country. As it was considered that much study and investigation must go into any decision as to reorganization, the committee summarized arguments for and against combination of the two existing reference librarians sections 
(ACRL and PLD) and recommended further study.

The Committee on Wilson Indexes, appointed by this section and by the Reference Section of the Public Libraries Division of ALA, met at least once a month from September I953 to April 1954. The ACRL section's chairman was Mr. Jerome K. Wilcox. The committees were primarily concerned this year with the International Index, and at the close of the year reported that strong support had been shown for elimination of all foreign language titles, titles indexed adequately elsewhere, and titles in the field of the natural sciences.

The Joint ARL-ACRL Committee on the Reproduction of Bibliographical and Reference Works reported in June that it had abandoned its work to a new group, the Joint Committee on Reprinting, which expected to establish a Reprint Expediting Office in New York in the fall of 1954 , to be supported by small grants from ALA divisions, library associations, publishers, and individual libraries.

The Committee on New Reference Tools reported two projects of principal importance, the new Cyclopedia of Education, and Charles Hamilton's revision of the Street Directory of the Principal Cities of the U.S. The former is still in the planning stage, and the latter is hoped for in about six months. Six other titles which were listed on last year's questionnaire as "most important" have been studied by the committee and specifications drawn up for the guidance of possible publishers.

The ALA Annual Conference meeting of the section was held on June 24, I954 at the Radisson Hotel in Minneapolis. The program consisted of a panel discussion of "Current Issues in Periodical Indexing."
The chief business of the meeting was a discussion of the proposal for divisional reorganization. It was moved and voted that the Committee to Study the Question of the Desirability of Establishing a New Reference Division should be continued and should report at the Annual Conference in 1955.

As stated in the Newsletter issued in April, special thanks should be expressed to Miss Frances Stalker, chairman, 1952-53, for turning over the business of the section in good shape at the end of her term; to Miss Elizabeth Bond, vice-chairman, for assistance in putting on the meeting at the Midwinter Conference; to Miss Knox, secretary, for very efficiently and helpfully carrying out her duties this year; and to Miss Gifford, who has been a most indefatigable and useful director and committee chairman, and has provided continuing guidance to members and officers since 1952. Particular thanks also to $\mathrm{Mr}$. Arthur $\mathrm{Hamlin}$, executive secretary of ACRL, for his friendly and able assistance on many problems.

(ETM)

\section{University Libraries Section}

\section{(Lawrence C. Powell, Chairman)}

The chairman reports, in letter form:

"Under my chairmanship, the University Libraries Section did absolutely nothing more than participate in two meetings, the one in Los Angeles a year ago and the Midwinter meeting in Chicago. The first was on branch libraries and the second dealt with the problem of whether the chief librarian should be a bookman and/or administrator. Papers of the latter meeting have appeared in COLLEGE AND RESEARCH LIBRARIES. Upon taking office, I found no committees active and took no steps to activate any."

(LCP)

\section{Chapters}

ACRL chapters are of very recent origin. This is really the first year in which our five chapters have had opportunity to get down to constructive work.

It appears to me that the chapters have been considerably more useful than was anticipated by many. The national tie has apparently been a spur to local organization. I attended meetings of the Missouri, Illinois and Tri-State (Pittsburgh area) chapters.
The first was devoted to organization and, therefore, was without special accomplishment. The Tri-State Chapter meeting was extremely useful and successful. Under the able organization of President Hugh Behymer, it provided an excellent blend of the instructional, social and recreational, and drew an excellent attendance from all over western Pennsylvania, eastern Ohio and West Virginia. The Illinois Chapter meeting was at the same time 
a meeting of the Illinois Library Association's College and Reference Libraries Section. It was at this meeting that plans were formulated to have a special meeting of midwestern college, university and research librarians at the time of the ALA Midwinter meeting. The Philadephia Area Chapter has had meetings of great interest, and New Jersey has had similar accomplishment. I have heard quite a bit of favorable comment about the several chapters and very little that was unfavorable. College librarians who feel a need for more local organization and professional discussion in their area should investigate the ACRL chapter device (details cheerfully supplied on request). The chapter may be more important than the state representative plan, making the association more meaningful to the average member and in drawing on the talents of those who are not known nationally.

(ATH)

\section{Philadelphia Area Chapter}

\section{(Alphonse F. Trezza, Chairman)}

The winter meeting of the Philadelphia chapter was held on February 8, 1954. In a brief business meeting, reports were given of the ACRL meetings at the Midwinter conference at Chicago the previous week.

A panel discussion on the subject of "Orienting the Student in the Use of the Library" was the topic of the evening meeting. Representatives from five colleges and universities provided a very lively discussion in which the audience participated.

On Saturday, May I5, I954, a joint meeting of the Philadelphia chapter of ACRL and the College and Reference Section of PLA was held at the new library of the Pennsylvania Military College. The subject for the all-day conference was "Serials and Periodicals in the Library." The guest speaker at the opening session was Mr. Wyllis E. Wright. The opening meeting was followed by workshops held in the late morning for their first session and after luncheon for their second session. The conference was closed by a general meeting to sum up the day's activities.

Mrs. Barbara K. Wright, head, Catalog Division, Temple University, was elected secretary-treasurer and $\mathrm{Mr}$. William D. Lewis, librarian, University of Delaware, was elected director.
As of May 31, 1954, the Philadelphia chapter has eighty-three dues-paying members. The treasury balance is $\$ 100.27$ with two small bills still outstanding.

(AFT)

\section{New Jersey State Chapter}

\section{(Theodore Epstein, President)}

The New Jersey State Chapter is the College and University Section of the New Jersey Library Association. Meetings were held under President Ada J. English on November 7 at Princeton University Library and on April 23 at Atlantic City. Noteworthy accomplishment during the year was the inauguration of exchange between colleges and universities of annual reports and other library publications on a large scale.

ACRL membership was promoted through the newsletter and at state meetings. Theodore Epstein was elected president of the section and the chapter for the coming year. Dr. William. S. Dix is president-elect, and Miss Doris Perry is secretary-treasurer.

\section{Illinois State Chapter}

\section{(Martha Biggs, Chairman)}

On November 6, I954, the College and Reference Libraries Section of the Illinois Library Association held its annual meeting, Mr. Benjamin B. Richards, chairman, presiding.

The membership felt that an effort should be made to have more meaningful meetings on the level of practical librarianship, and that there was a possibility that regional meetings of some kind could be arranged. An exploratory committee consisting of Dr. Robert B. Downs, Mr. David Jolly, Mr. Benjamin B. Richards, and Dr. Robert H. Muller, chairman, was appointed to investigate the feasibility of planning annual meetings of midwestern college, university and research librarians.

During the Midwinter ALA conference, a closed meeting of midwestern librarians was held to discuss this idea. The response was favorable and it was decided that arrangements should be made for a session to be held in February, I955 at the University of Chicago campus. Emphasis will be placed on small discussion groups encompassing all professional college and research librarians, the 
subject matter to be suggested by the participants.

A panel discussion, "Books for an Ideal College Library," based on the new Catalogue of the Lamont Library was led by Dr. Leon Carnovsky. This featured Mr. Philip J. McNiff of Harvard, editor of the catalog. Dr. Robert H. Muller spoke on its implications for other libraries.

(MLB)

\section{Missouri State Chapter}

(Kenneth J. LaBudde, Chairman)

The initial meeting of the Missouri chapter of ACRL was held on October 3, 1953, at the University of Kansas City, with members of the College and University Division of MLA and the Kansas City and St. Louis chapters of SLA attending. Kenneth J. LaBudde, after reviewing the steps taken to make a Missouri chapter possible, introduced Arthur Hamlin who spoke on the potentialities of local chapters.

The Missouri chapter is not interested in an elaborate organization but prefers to function within the present organization of the College and University Division expanded to include members of reference libraries, both special and public, interested in ACRL activities. It was voted to ask permission of the executive board of MLA to change the name of the division so as to recognize the expanded membership. Plans were made for mutual assistance on the college project of a checklist of special collections in Missouri libraries and the SLA chapters' projects of a revision of the Kansas City area union list of serials and of the directories of the two chapters.

$(\mathrm{KJL})$

\section{Tri-State Chapter}

\section{(E. Hugh Behymer, President)}

The organization meeting of the Tri-State Chapter of ACRL was held in the faculty club at Duquesne University on November 7, 1953. Miss Esther Fawcett, fine arts librarian, Carnegie Institute of Technology, Pittsburgh, presided. She spoke first of all of the reasons for the establishment of this chapter, announced that the chapter had been approved by the American Library Association, and called for a report of the Nominating Committee. This committee pre- sented the following names: E. Hugh Behymer, librarian, Bethany College, Bethany, West Virginia, president; Mr. John Nicholson, Jr., librarian, Kent State University, Kent, Ohio, vice-president; Miss Mabel Kocher, librarian, Westminster College, New Wilmington, Pennsylvania, secretary-treasurer; Miss Rose Demorest, librarian of the Pennsylvania Room, Carnegie Library of Pittsburgh, and Miss Geraldine Anderson, librarian, Consolidated Coal Company $\mathrm{Li}$ brary, Pittsburgh, Pennsylvania, executive board members. There were no other nominations and the nominees were elected by unanimous vote.

The second meeting of the Tri-State Chapter was held on February 13, 1954, at the Fairfax Hotel in Pittsburgh. The meeting was called by President Behymer to discuss and approve a constitution and bylaws for the new chapter. There were approximately fifty interested librarians present. Each article and section of the proposed constitution was discussed and approved separately. At the end of the afternoon, the new constitution and bylaws were presented to the group and they were unanimously approved.

The western Pennsylvania, eastern Ohio, and West Virginia chapter of ACRL met on May I, I954, at Bethany College, Bethany, West Virginia. The meeting was called to order at I I:OO a.m. by the president. Previous minutes were read by the secretary. The Bethany College Male Chorus presented several musical numbers. Old and new business of the association was discussed. The meeting adjourned in time for visitors to see the college. At the luncheon meeting, greetings from the college were presented by Dean B. R. Weimer, chairman of the Faculty Library Committee. President Behymer presented Mrs. Emilie Jacobson who spoke on "Humor-Weapon of Free People." Following the luncheon, the meeting was called to order by the president and he presented the president's address: "The Philosophy of $\mathrm{Li}$ brarianship." He then introduced Mr. Arthur Hamlin, executive secretary of the ACRL who talked to the group on "What the ACRL can do for you." His talk was followed by a question period. After the meeting adjourned, tea was served in the main reading room of the library by the wives of the Faculty Library Committee.

(EHB) 